\title{
Emissions of polycyclic aromatic hydrocarbons (PAH) from creosoted railroad ties and their relevance for life cycle assessment (LCA)
}

\author{
M. Kohler, T. Künniger
}

Abstract Based on the analysis of cross sections of railroad ties, which were in use for up to 46 years, inventory, emission factors and total yearly emissions of creosote, $\mathrm{PAH}$ and phenols from the Swiss railway network were determined. During the service time of a railroad tie of 20 to 30 years, roughly $5 \mathrm{~kg}$ creosote are emitted. $\mathrm{PAH}$ emissions are in the order of about $0.5 \mathrm{~kg}$ (sum of $16 \mathrm{EPA}$ $\mathrm{PAH}$ ) and occur as emissions of the volatile 2- and 3-ring PAH (such as naphthalene, acenaphthylene, acenaphthene, anthracene, fluorene, and phenanthrene). Emissions of phenolic compounds are in the range of $10 \mathrm{~g}$ for each tie. According to our study, about $1710 \mathrm{t}$ of creosote components, $139 \mathrm{t}$ of EPA-PAH and $4 \mathrm{t}$ of phenolic compounds are emitted by the creosoted ties of the Swiss railway network, every year. Based on these results and on a previous study on environmental life cycle assessment (LCA) of railway ties made of creosoted beech, prestressed concrete and sectional steel, the environmental effects caused by wooden ties were compared with the environmental effects of rail and road traffic. The PAH emissions from wooden ties have an enormous influence on the two effect oriented impact categories photochemical ozone creation and human toxicity. For all other impact categories, the $\mathrm{PAH}$ emissions are not relevant. If the road traffic (including its upstream processes) is included in the LCA, it is clearly dominating all impact categories. The use of new creosotes according to the WEI-C standard (lower benzo[a]pyrene content, less evaporation) improves the

\section{Published online: 11 March 2003}

\section{Kohler ( $\otimes)$}

Laboratory of Organic Chemistry, Swiss Federal Laboratories for Materials Testing and Research (EMPA), Überlandstrasse 129, 8600 Dübendorf, Switzerland

E-mail: martin.kohler@empa.ch

Fax: +41-1-8234041

\section{T. Künniger}

Wood Laboratory, Swiss Federal Laboratories for Materials Testing and Research (EMPA), Überlandstrasse 129, 8600 Dübendorf, Switzerland

This work has been funded by the Swiss Agency for the Environment, Forests and Landscape (BUWAL) and by the Swiss Federal Laboratories for Materials Testing and Research (EMPA). Support (railroad tie and creosote samples) from the Swiss Federal Railways and from industry (Corbat sa, Glovelier, Switzerland; VFT AG, Castrop-Rauxel and Hahnau, Germany; Cindu Chemicals, Uithoorn, The Netherlands) is gratefully acknowledged. rating in the impact category photochemical ozone creation. Less than $14 \%$ of the total impact are caused by $\mathrm{PAH}$ emissions if creosote WEI-C is used, compared to more than $50 \%$ for creosote WEI-A. The LCA also demonstrates that the most effective measure to reduce the potential of photochemical ozone creation and human toxicity is a reduction of the road traffic.

\section{Emissionen von polyzyklischen aromatischen Kohlenwasserstoffen (PAK) aus teerölbehandelten Eisenbahnschwellen und ihre Bedeutung bei der Ökobilanzierung}

Zusammenfassung Gestützt auf die Analyse von Querschnittsprofilen durch ausgewählte Eisenbahnschwellen, die bis zu 46 Jahre lang im Einsatz waren, wurden Inventar, Emissionsfaktoren und totale jährliche Emissionen von Teeröl, PAK und Phenolen aus dem Schweizer Schienennetz bestimmt. Eine teerölbehandelte Eisenbahnschwelle (Buchen- oder Eichenholz) emittiert während einer Einsatzdauer von 20 bis 30 Jahren rund $5 \mathrm{~kg}$ Teeröl. PAK Emissionen liegen im Bereich von etwa $0,5 \mathrm{~kg}$ (Summe der 16 EPA-PAK) und liegen als Emissionen der flüchtigen 2und 3-Ring PAK (Naphthalin, Acenaphthylen, Acenaphthen, Anthracen, Fluoren und Phenanthren) vor. Die Emissionen phenolischer Verbindungen liegen im Bereich von $10 \mathrm{~g}$ pro Schwelle. Gemäss unseren Untersuchungen werden aus den teerölbehandelten Eisenbahnschwellen des schweizerischen Schienennetzes pro Jahr rund $1710 \mathrm{t}$ Teeröl, 139 t EPA-PAK und $4 \mathrm{t}$ phenolische Verbindungen emittiert.

Basierend auf diesen Resultaten und einer bereits veröffentlichten Studie zur ökologischen Bewertung von Streckenschwellen aus vorgespanntem Beton, Profilstahl und teerölimprägniertem Buchenholz in der Schweiz wurden die Umwelteinflüsse von teerölbehandelten Eisenbahnschwellen mit denen des Schienen- und Strassenverkehrs verglichen. Die PAK Emissionen aus teerölbehandelten Holzschwellen haben einen enormen Einfluss auf die beiden effektorientierten Bewertungsparameter photochemische Ozonbildung und Humantoxizität. Für alle anderen Bewertungsparameter sind die PAK Emissionen nicht relevant. Falls der Strassenverkehr (inklusive Vorketten) mit in den Vergleich einbezogen wird, dominiert dieser alle Bewertungskategorien klar. Der Einsatz des neuen Teeröl nach WEI-C (tieferer Benzo[a]pyren Gehalt, tiefere Verdunstungsneigung) stellt in Bezug auf die photochemische Ozonbildung eine klare Verbesserung dar. Weniger als 14\% der Gesamtbelastung werden erreicht, wenn Teeröl nach WEI-C eingesetzt wird, 
verglichen mit 50\% im Falle von Teeröl nach WEI-A. Die ökologische Bewertung zeigt, dass die Bedeutung der PAKEmissionen aus Holzschwellen im Vergleich zu anderen Emissionsquellen des Verkehrs gering ist. Ein größeres Potential zur Reduktion der Bewertungsparameter photochemische Ozonbildung und Humantoxizität besteht in einer Reduktion des Strassenverkehrs, insbesondere des motorisierten Individualverkehrs.

\section{1}

\section{Introduction}

Polycyclic aromatic hydrocarbons (PAH) are ubiquitous environmental pollutants which are emitted by various sources, such as internal combustion engines, furnaces and industrial processes. Railroad ties treated with creosote have been in use for more than 150 years (Streckert 1989). Creosote-a product manufactured by distillation of coal tar-contains up to $85 \%$ PAH (Gevao and Jones 1998). About $20-40 \%$ of the contents of a typical creosote can be attributed to the $16 \mathrm{PAH}$, defined as priority pollutants by the U.S. Environmental Protection Agency (EPA-PAH). The content of benzo[a]pyrene-a typical carcinogenic $\mathrm{PAH}$ - in creosote, is limited by current specifications issued by the Western-European Institute for Wood Preservation (WEI).

Although wood treated with creosote represents a significant inventory of $\mathrm{PAH}$, there are few studies reporting on the quantitative assessment of emissions from this particular source. Based on laboratory measurements of PAH emissions from planks of Yellow Pine painted with creosote, Gevao and Jones (1998) estimated the annual U.K. emissions for acenaphthene, fluorene, phenanthrene, anthracene and fluoranthene from freshly treated wood to be $100 \mathrm{t}$. Data on leaching experiments on railroad ties were published by Cooper (1994). A standard shower test for freshly treated wood was developed in the Netherlands, specifying a maximum leaching limit of $2500 \mathrm{mg} \mathrm{PAH}$ (sum of 21 species) per $\mathrm{m}^{3}$ treated wood (Havermans 1993). In an extensive field study at a site near Monrovia (Liberia) on creosote emissions from railroad ties, more than 600 railroad ties were treated with creosote, selected according to their creosote content, installed and reanalyzed after several years of exposure (Petrowitz et al. 1976 and 1991). Other field studies include long term experiments on poles treated with creosote being exposed for several decades (Hudson 1997; Bergqvist 1994), indicating loss of the low boiling PAH by evaporation and partial transfer of the high boiling $\mathrm{PAH}$ into the surrounding soil.

In the light of a study on life cycle assessment of railroad ties at Swiss Federal Laboratories for Materials Testing and Research (Künniger and Richter 1998) and on emission assessment of PAH by the Swiss Agency for the Environment, Forests and Landscape (BUWAL) on a European level (OSPARCOM 1996), we decided to assess the emissions of $\mathrm{PAH}$ form the Swiss railway network. Emission factors for $\mathrm{PAH}$, creosote and phenols were determined through analysis of cross sections of selected railroad ties treated with creosote (age between 0.5 and 46 years, beech and oak). From this data, yearly emissions for the Swiss railway network from all creosote impregnated wooden railroad ties have been extrapolated. In the study by Künniger and Richter cited above, an environmental life cycle assessment (LCA) on railroad ties made of creosote impregnated beech, prestressed concrete and sectional steel as used on main lines of Switzerland's railways was presented. All extractions from and insertions into the environment which were connected with manufacturing, use and disposal of the different types of ties were inventorized and assessed, including the data on $\mathrm{PAH}$ emissions. The aim of this study was the determination of the environmental effects caused by creosoted wooden ties, including the PAH emissions. The environmental effects caused by wooden ties were compared with the environmental effects caused by rail and road traffic. This procedure allows to estimate the ecological relevance of the PAH emissions from creosoted railroad ties in Switzerland.

\section{2}

\section{Materials and methods}

The determination of emissions of PAH, creosote and phenolic components was based on two assumptions: First, the composition of the creosote used for treatment of a railroad tie can be approximated by the composition of the creosote extracted from the center of the railroad tie. This was verified by data obtained by boiling range analysis of creosote extracted from used railroad ties and by comparison of creosote concentration profiles of railroad ties of different age (Kohler 2000). Second, railway ties were treated with typical amounts of creosote of $160 \mathrm{~kg} / \mathrm{m}^{3}$ (beech wood) and $60 \mathrm{~kg} / \mathrm{m}^{3}$ (oak wood) as required by standards set by the Swiss Federal Railways several decades ago (Schwanninger 1998).

\section{1}

\section{Samples}

In cooperation with the Swiss Federal Railways and industry, a set of 6 railroad ties at ages of $0.5,1,6,19,32$ and 46 years made from beech and oak wood was selected. Across each tie, 8 samples were taken at $10 \%, 33 \%$ and $50 \%$ of the total length. Shavings $(0.25 \mathrm{~mm})$ of the samples from each level were pooled to compensate for inhomogenities (see Fig. 1). Each of the pooled samples represents $2 \mathrm{~cm}$ of the cross section of a tie, running from the top (sample 1) to the bottom (sample 8).

\section{2 \\ Chemical and physical analysis}

From each sample, $5 \mathrm{~g}$ were extracted with $200 \mathrm{ml}$ of a mixture of toluene and methanol (8:2) for 4 hours. Creosote contents were determined gravimetrically. The boiling range of the extracted creosote residues was determined by gas chromatography (SimDis method, according to DIN 51435). Total phenol contents were determined by UV/vis spectrophotometry according to ASTM 1783-91 (4-aminoantipyrin method). The concentrations of the $16 \mathrm{EPA}-\mathrm{PAH}$ were measured by gas chromatography/high resolution mass spectrometry using naphthalene- $\mathrm{d}_{8}$, anthracene- $\mathrm{d}_{10}$, chrysene- $d_{12}$, perylene- $d_{12}$, and benzo[ghi] perylene- $d_{12}$ as internal standards, pyrene- $d_{10}$ as syringe standard and acenaphthene- $d_{10}$ as a recovery standard. 


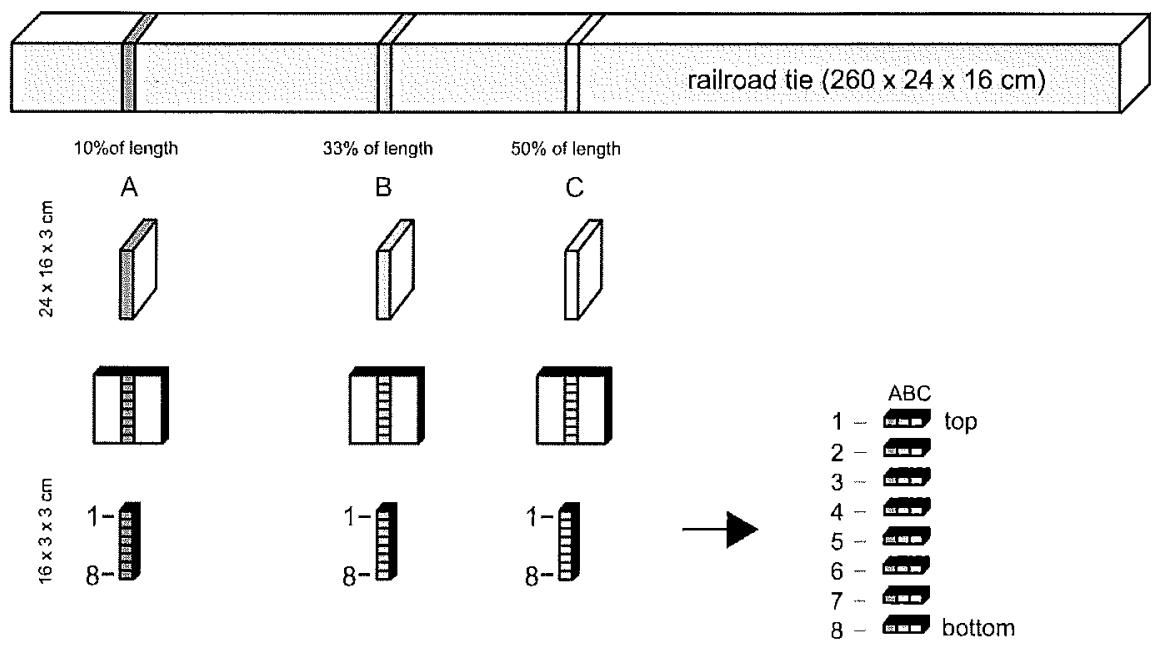

Fig. 1. Obtaining representative wood samples from railroad ties. From 3 locations, 8 samples across the profile of the tie were taken and pooled

Abb. 1. Entnahme repräsentativer Holzproben von Bahnschwellen. Von 3 Orten wurden 8 Proben entlang dem Querschnitt der Schwelle entnommen und vereinigt

\section{3}

\section{Data on the Swiss railway network}

The total length of the Swiss railway network (including private railways) is $12518 \mathrm{~km}$ (based on data from 1999). Presently, an estimated number of about 8.9 million wooden railroad ties are in service in Switzerland; this accounts for $43 \%$ of the ties installed. Next to ties made from beech and oak wood, sectional steel ties (35\%) and prestressed concrete ties (22\%) are used.

\section{4}

\section{Life cycle assessment (LCA)}

\subsection{1}

\section{LCA of railway ties}

Data collection and assessment were carried out following the basic recommendations of ISO $14040 \mathrm{ff}$ (methodology of product LCA, see Fig. 2).

\section{4 .2}

\section{Goal definition and scope}

The study was carried out on railway ties made of creosoted beech wood, prestressed concrete and sectional steel as used on the main lines by the Swiss Federal Railways (see Table 1). Included in the analysis from cradle to grave were the ties themselves, the auxiliary materials and a part of the impacts caused by the construction work as well as by the maintenance of the track bed $(0.6 \mathrm{~m} / \mathrm{tie})$, and its transport. The different statistical service life of the three types of ties and their disposal were included in the

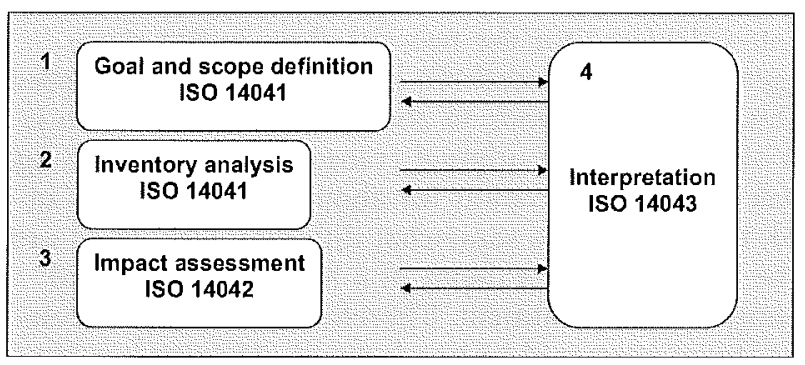

Fig. 2. Structure of a product LCA according to ISO 14040 Abb. 2. Aufbau einer Produktökobilanz gemäß ISO 14040 comparison, as well. The impact of reuse and recycling loops, relevant for most of the steel components, are recognized in the inventories using appropriate allocation models.

\subsection{3}

\section{Data inventory}

Production data were collected in Swiss plants in close collaboration with the manufacturers. Extensive data inventories of all materials, energy forms and transport processes directly associated with the functional units were established. Data for service life (including maintenance, repair and restoration processes) as well as for disposal were provided by the Swiss Federal Railways. Up to now, only inadequate quantitative emission data on creosote components over the long service time of a creosoted railway tie were available in literature. Modelling the emissions based on a worst case scenario, we estimated that $45 \%$ of the original components are lost by evaporation during a service life of 30 years. Now these emission data have been verified (Kohler 2000). All data (measured and modelled) were entered into the database of the software system EMIS (EMIS, version 3.0, Carbotech 2000) and combined with the environmental inventories of standard processes (Frischknecht et al. 1996).

\subsection{4}

\section{Impact assessment}

The assessment of the environmental impacts was carried out on the basis of seven effect-oriented impact categories proposed by Heijungs et al. (1992). Additionally, the primary energy consumption and entries in landfills were calculated.

\subsection{5}

\section{Data evaluation of road traffic and rail traffic}

Data on traffic in Switzerland in 1995 is shown in Table 2. This transport data were combined with the environmental inventories of standard transport processes (Maibach et al. 1995). The same method was used to assess the environmental impacts caused by ties and traffic. The calculated environmental impacts caused by ties including track beds were compared to the environmental impacts 
Table 1. Material profiles of the functional units (railroad tie)

Tabelle 1. Materialprofile der funktionalen Einheiten (Bahnschwelle)

\begin{tabular}{lllllll}
\hline Railroad Tie Type & Steel $[\mathrm{kg}]$ & Wood $[\mathrm{kg}]$ & Creosote $[\mathrm{kg}]$ & Concrete[kg] & Tie Total $[\mathrm{kg}]$ & $0.6 \mathrm{~m}$ Track Bed $[\mathrm{kg}]$ \\
\hline Concrete tie & 14.0 & - & - & 258.0 & 273 & 1920 \\
wood tie & 25.5 & 62.0 & 15.2 & - & 103 & 1620 \\
steel tie & 91.0 & - & - & - & 91 & 1740 \\
\hline
\end{tabular}

Table 2. Total traffic in Switzerland in 1995(Pkm: passenger kilometers; tkm: tonne-kilometers; source: Swiss Federal StatisticalOffice)

Tabelle 2. Verkehrsaufkommenin der Schweiz im Jahre 1995

(Pkm: Personenkilometer; tkm: Tonnenkilometer; Quelle:Schweizer Bundesamt für Statistik)

\begin{tabular}{lrl}
\hline PrivateRoad Traffic & 73194 & \\
cars & 1516 & MioPkm \\
motorcycle & 410 & MioPkm \\
motorbikes & 2327 & MioPkm \\
coach & & \\
goodsroad traffic & 686 & Miotkm \\
truck,total weight $<3.5 \mathrm{t}$ & 12182 & MioPkm \\
$\begin{array}{l}\text { truck,total weight }>3.5 \mathrm{t} \\
\text { privaterail traffic }\end{array}$ & 13408 & MioPkm \\
railroad & & \\
$\begin{array}{l}\text { (1/3of each slow train, } \\
\text { regional train, fast train) }\end{array}$ & & \\
goodsrail traffic* & & \\
RLS(trucks carried by train) & 434 & Miotkm \\
UKV(container) & 2780 & Miotkm \\
WLV(wagon) & 5472 & Miotkm \\
\hline
\end{tabular}

* source: Swiss FederalRailways 1995

Mio Pkm: passenger kilometers (millions)

Mio tkm: tonne-kilometers (millions)

caused by rail and road traffic. The PAH emissions from creosote treated wooden ties (based on creosote WEI-A as used in the past, and on creosote WEI-C as used today), are presented separately.

\section{Results and Discussion}

\section{1}

\section{Creosote-specifications and composition}

Specifications for creosote were issued by various institutions such as the Western-European Institute for Wood Preservation (WEI standards WEI-A, WEI-B and WEI-C) and the American Wood Preservers' Association (AWPA Standards P1/P13 and P2, Webb 1998). The use of creosote is regulated by the European Community (The Commission of The European Communities 1999). Until 1994, railroad ties installed in Switzerland were treated with creosote according to the WEI-A standard. Between 1994 and 1997, railroad ties treated with creosote according to WEI-B, containing less high boiling components (boiling range $210-400^{\circ} \mathrm{C}$, benzo[a]pyrene contents below $50 \mathrm{ppm}$ ), were installed. Starting from 1998, the Swiss Federal Railways are exclusively installing ties treated with creosote according to WEI-C (boiling range $250-400^{\circ} \mathrm{C}$, benzo[a]pyrene contents below $50 \mathrm{ppm}$ ). Since no railroad ties treated with creosote according to WEI-C of sufficient age (20-30 years) are available today, this study focuses on the conventional creosote according to WEI-A.
$\mathrm{PAH}$ concentrations in 9 commercially available creosotes according to WEI-A, WEI-B and WEI-C were measured. Levels of benzo[a]pyrene in commercial creosotes between 2 and $159 \mathrm{ppm}$ were found. These values are low, compared to levels of benzo[a]pyrene of more than $2000 \mathrm{ppm}$, detected in creosotes extracted from used railroad ties. As shown in Fig. 3, creosote according to WEI-C contains significantly lower amounts of the high boiling $\mathrm{PAH}$ fractions which are responsible for the carcinogenic properties of creosote. Also, the content of naphthalene, being the most volatile of the $16 \mathrm{EPA}-\mathrm{PAH}$ determined, is significantly lower. However, the contents of the 3-ring and some 4-ring $\mathrm{PAH}$ (acenaphthene, anthracene, fluorene, phenanthrene, fluoranthene and $\mathrm{py}$ rene) are higher in creosote according to WEI-C than in creosote according to WEI-A. This effect is mainly due to the fact, that WEI-C consists of the medium-boiling fractions of the coal tar distillate (boiling range $250-400^{\circ} \mathrm{C}$ ).

\section{2}

\section{Creosote, PAH and phenols emissions}

According to standards set by the Swiss Federal Railways several decades ago, railroad ties were treated with $160 \mathrm{~kg}$ (beech wood) and $60 \mathrm{~kg}$ (oak wood) creosote per $\mathrm{m}^{3}$ (Schwanninger 1998). These amounts correspond to $15 \mathrm{~kg}$ creosote for a beech wood tie and $6 \mathrm{~kg}$ creosote for a oak wood tie. Due to the nature of the impregnation process, concentrations of creosote decrease towards the center of the railroad tie. Figure 4 shows the creosote content of a new railroad tie compared to a railroad tie which was in use for 32 years. Comparing the two concentration profiles clearly demonstrates that creosote is lost from the outer layers of the used tie upon 32 years of exposure in the railroad track, leading to an inversion of the concentration profile. This inversion has already been described by Petrowitz (Petrowitz et al. 1976 and 1991). The authors report, that immediately after treatment, the concentration of creosote to a depth of $2 \mathrm{~cm}$ was found to be about 25 to $35 \%$ higher than at a depth of 8 to $10 \mathrm{~cm}$. Losses of creosote observed were $8 \%$ after 2 years, $18 \%$ after 5 years and $27 \%$ after 10 years service time. The total contents of creosote calculated for the two ties show in Fig. 4 are $155 \mathrm{~kg} / \mathrm{m}^{3}$ for the new and $105 \mathrm{~kg} / \mathrm{m}^{3}$ for the used railroad tie. This loss corresponds to about $5 \mathrm{~kg}$ per tie, which is about one third of the original creosote contents of $15 \mathrm{~kg}$. For oak ties, which account for about $20 \%$ of the ties installed, the situation is somewhat different. Oak wood can only be penetrated to a depth of a few $\mathrm{cm}$ by standard vacuum-pressure treatment. Therefore, the creosote content is lower compared to beech wood $\left(60 \mathrm{~kg} / \mathrm{m}^{3}\right.$, corresponding to $6 \mathrm{~kg}$ for a typical oak wood tie). Since all creosote is concentrated in the parts close to the surface, 


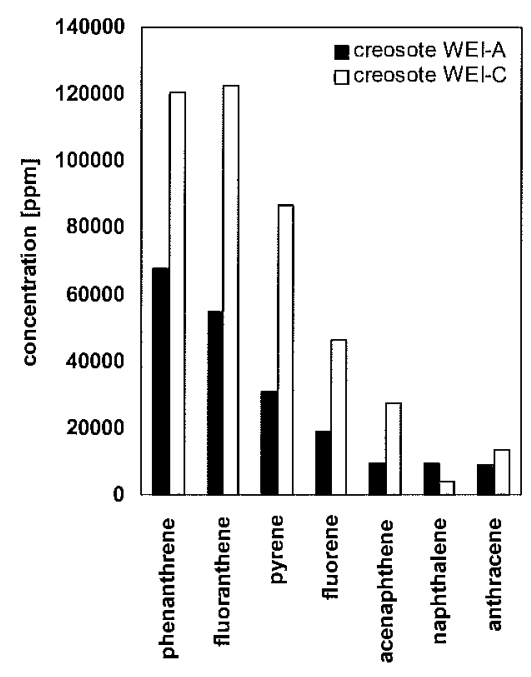

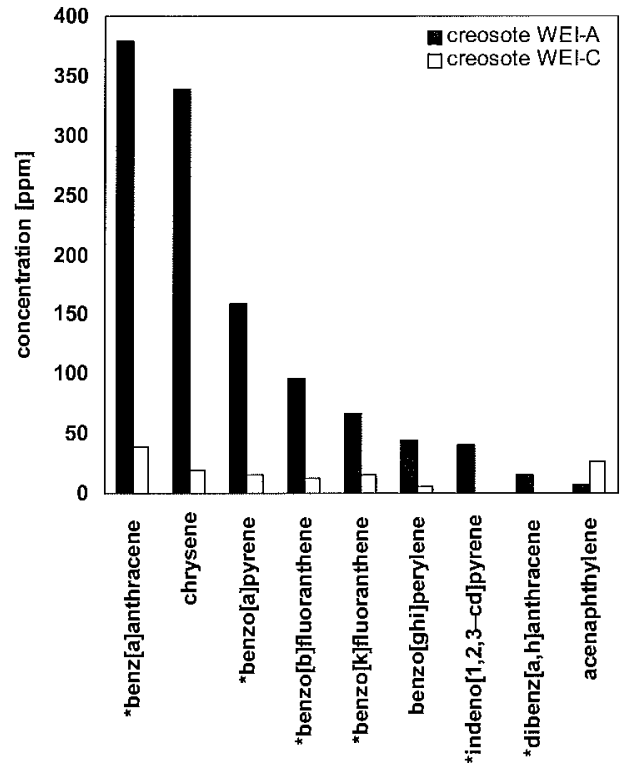

Fig. 3. PAH profiles of two creosotes according to WEI-A and WEI-C standards (*carcinogenic PAH according to the International Agency for the Research on Cancer, IARC)

Abb. 3. PAK Profile zweier Teeröle gemäß WEI-A und WEI-C Standard

( ${ }^{*}$ krebserzeugende PAK-Profile gemäß der "International Agency for the Research on Cancer", IARC) the amount of creosote lost upon the average service time is also about $5 \mathrm{~kg}$, which is the same amount found for railroad ties made of beech wood. Based on data obtained from beech and oak ties, standard concentration profiles reflecting the concentration profiles of new beech and oak ties were defied and compared to the 6 railroad tie samples, covering a time period between 0.5 and 46 years. Emitted quantities of creosote of $0.4 \mathrm{~kg}$ (beech, 0.5 years), $2.9 \mathrm{~kg}$ (beech, 1 year), $1.5 \mathrm{~kg}$ (beech, 6 years), $5.3 \mathrm{~kg}$ (oak, 19 years), $5.1 \mathrm{~kg}$ (beech, 32 years) and $5.0 \mathrm{~kg}$ (oak, 46 years) were calculated. From these data, we conclude that an average railroad tie looses about $5 \mathrm{~kg}$ creosote within a typical service time of 20 to 30 years.

Analysis of the concentrations of the $16 \mathrm{EPA}-\mathrm{PAH}$ in a new railroad tie (age 0.5 years) showed a constant concentration of each $\mathrm{PAH}$ species ( $\mathrm{PAH}$ profile) through the cross section of the tie. Thus, no enrichment or depletion processes are induced by the vacuum pressure treatment (Kohler 2000). For used ties, however, the picture looks

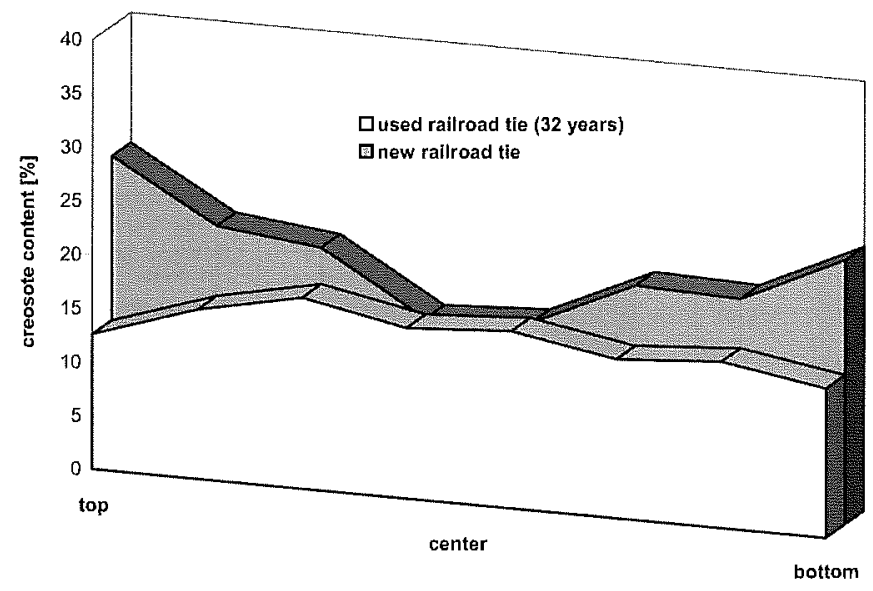

Fig. 4. Distribution of creosote in a new and used railroad tie as a function of depth

Abb. 4. Verteilung von Teeröl in einer neuen und einer gebrauchten Bahnschwelle als Funktion der Tiefe much different. Figure 5 shows the PAH profile of a railroad tie being in use for 32 years. Top and bottom of the tie are represented by black bars. The data given in Fig. 5 show several processes. First of all, emission of the volatile 2- and 3-ring PAH (naphthalene, acenaphthene, acenaphthylene, anthracene and fluorene) from top and bottom layers were clearly detected. In all cases, higher relative emissions were found on the top layer. In parallel, the loss of volatile compounds leads to an significant increase of the concentrations of the low volatile 4- to 6-ring $\mathrm{PAH}$ on top and bottom layers. Again, this effect is more pronounced on the top layer. Boiling range analysis of railroad ties being in service for up to 32 years showed that the original composition of the creosote remains unchanged in the center of the railroad tie (Kohler 2000). For this reason, the creosote extracted from the center can be taken as a reference for the composition of the creosote which was used for the impregnation of a particular tie. From this data, emissions of the individual PAH can be calculated, using the standard concentration profiles, the residual amounts of creosote and the $\mathrm{PAH}$ profile of the creosote extracted from the inner layers of the railroad tie (profile analysis method). Since this method is only applicable for beech wood ties-there is no reference creosote available from the inner layers of oak ties-only data for 4 samples could be calculated. Emitted quantities of $\mathrm{PAH}$ (sum EPA-PAH consisting of 2- and 3-ring EPA$\mathrm{PAH}$, only) of $0.15 \mathrm{~kg}$ (beech, 0.5 years), $0.44 \mathrm{~kg}$ (beech, 1 year), $0.19 \mathrm{~kg}$ (beech, 6 years), and $0.50 \mathrm{~kg}$ (beech, 32 years) were calculated. In all cases, no emissions of 4- to 6ring $\mathrm{PAH}$ could be detected. From these data, we conclude that an average railroad tie emits about $0.5 \mathrm{~kg} \mathrm{PAH}$ (sum EPA-PAH, consisting of 2- and 3-ring PAH, only) within a typical service time of 20 to 30 years. Due to the loss of the volatile species, concentrations of the 4- to 6-ring $\mathrm{PAH}$ are significantly increased in the top and bottom layers. 7Benzo[a]pyrene concentrations in creosote extracted from the outer layers of used railroad ties analyzed in this study were between 954 ppm (beech, 32 years) and 2061 ppm (oak, 19 years). High concentrations of 


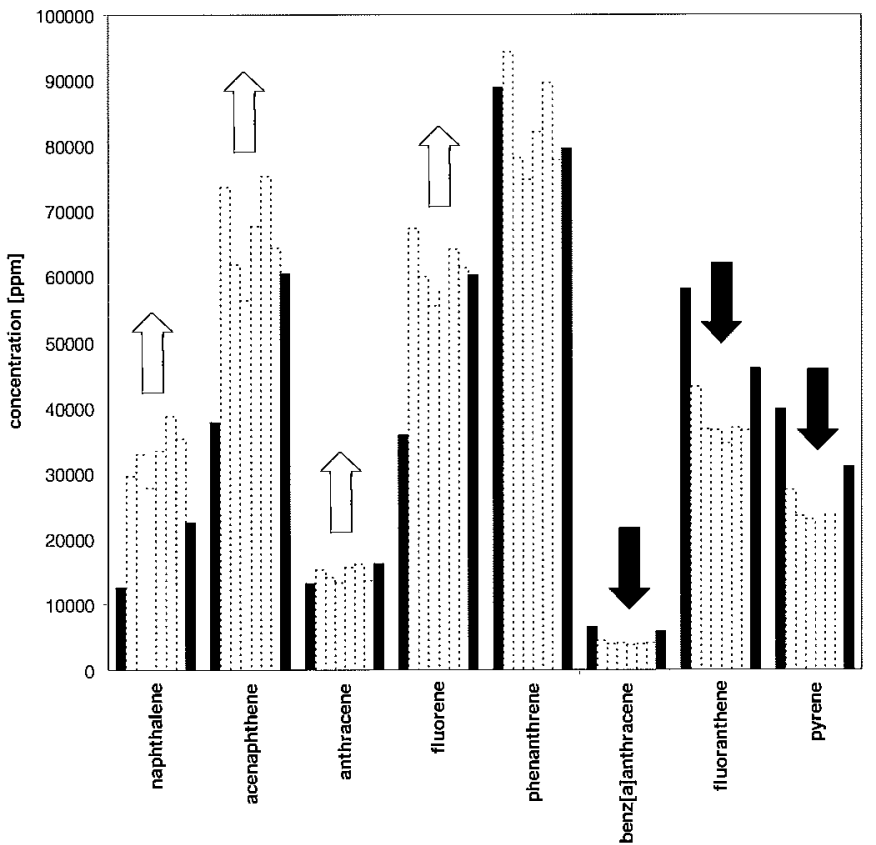

Fig. 5. PAH concentrations in creosote extracted from a used railroad tie. Each bar represents $2 \mathrm{~cm}$ of the cross section of the tie (black bars represent top and bottom layers)

benzo[a]pyrene in used railroad ties were also reported by Rotard and Mailahn (Rotard et al. 1987); levels of benzo[a]pyrene between $1830 \mathrm{ppm}$ and $10490 \mathrm{ppm}$ in creosote extracted from used railroad ties collected from various playgrounds were detected (corresponding to contents of $183 \mathrm{ppm}$ and $1573 \mathrm{ppm}$ in wood, calculated from Rotard et al. 1987). Emissions of phenols, a class of components which is also of interest from an environmental point of view were assessed for the beech wood railroad ties using the profile analysis method described above. Emissions were found to be in the range of $10 \mathrm{~g}$ for

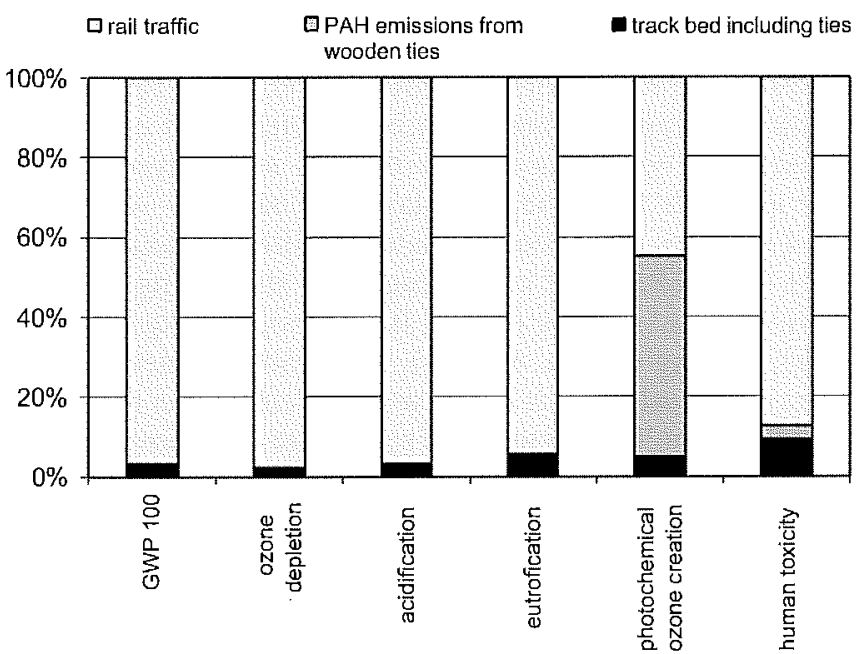

Fig. 6. Environmental impacts per year, based on rail traffic (Switzerland 1995)

Abb. 6. Umwelteinwirkungen pro Jahr, basierend auf dem Schienenverkehr (Schweiz 1995)

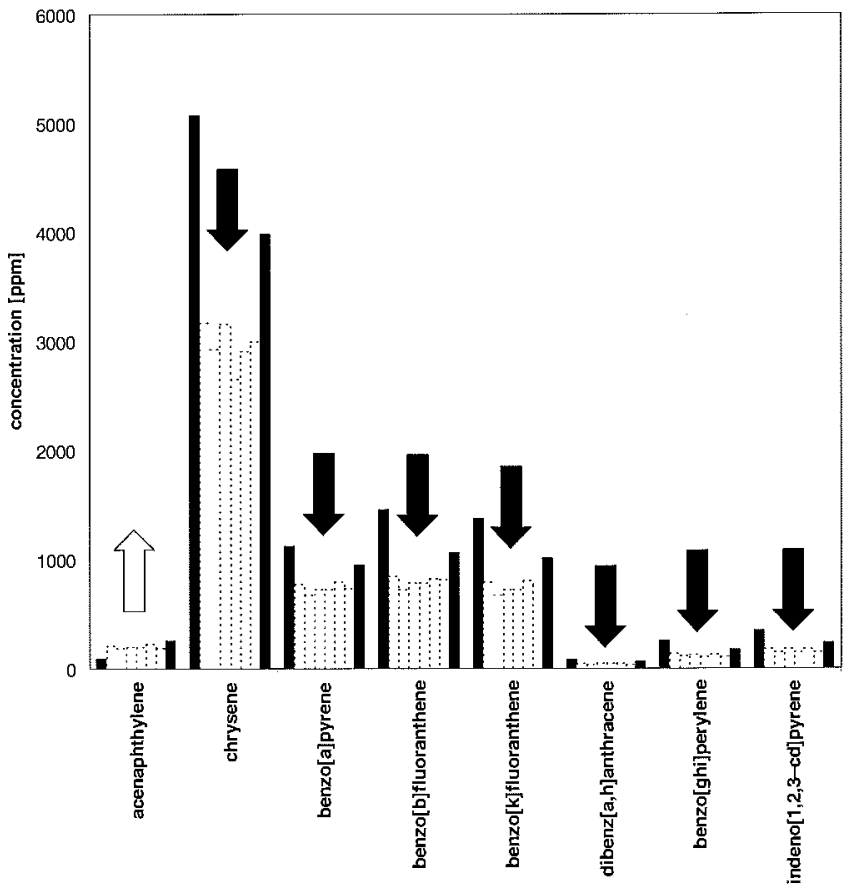

Abb. 5. PAK Konzentrationen in Teeröl, das aus einer gebrauchten Bahnschwelle extrahiert wurde. Jede Säule stellt $2 \mathrm{~cm}$ des Querschnitts der Bahnschwelle dar (die schwarzen Säulen symbolisieren die oberste und die unterste Schicht)

a tie being 32 years old. Alternatively, phenols emissions were estimated by the total loss of creosote of about $5 \mathrm{~kg}$ and an average content of phenolic compounds of $0.3 \%$ in creosote (determined from creosote extracted from the center of the same sample) to about $15 \mathrm{~g}$ in 32 years.

\section{3}

\section{Emission factors for creosote, $\mathrm{PAH}$ and phenols}

Based on the emitted quantities, surface area and age of the railroad ties investigated, emission factors can be calculated. Emission factors of $208 \mathrm{mg} /\left(\mathrm{m}^{2} \times\right.$ day $)$ for creosote, $0.58 \mathrm{mg} /\left(\mathrm{m}^{2} \times\right.$ day $)$ for phenols and $20.3 \mathrm{mg} /$ $\left(\mathrm{m}^{2} \times\right.$ day $)$ for 2- and 3-ring PAH were calculated. These values are in good agreement with studies published by other authors. Gevao and Jones (1998) report mean total
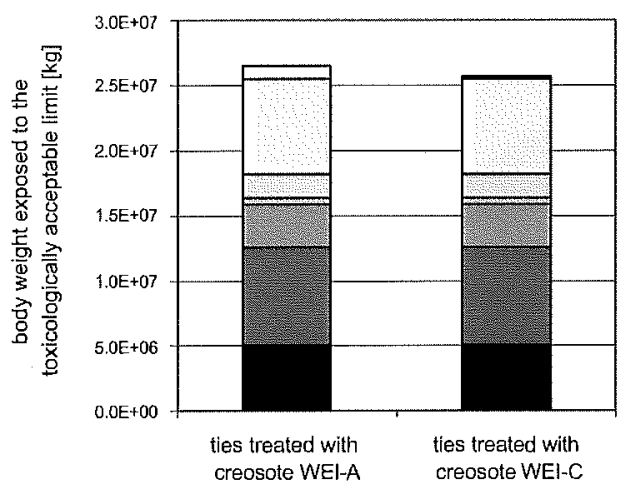

OPAH emissions from wooden ties 口carriage of goods WLV (wagon) $\square$ carriage of goods UKV (conlainer) $\square$ carriage of goods RLS (trucks carried by train) ๑passeriger transport, fast 由. regional trai Dassenger transport, slow
train creosole WEI-A creosote WEI-C

Fig. 7. Impact category "human toxicity" per year, based on rail traffic (Switzerland 1995)

Abb. 7. Bewertungskategorie "Humantoxizität" pro Jahr, basierend auf dem Schienenverkehr (Schweiz 1995) 


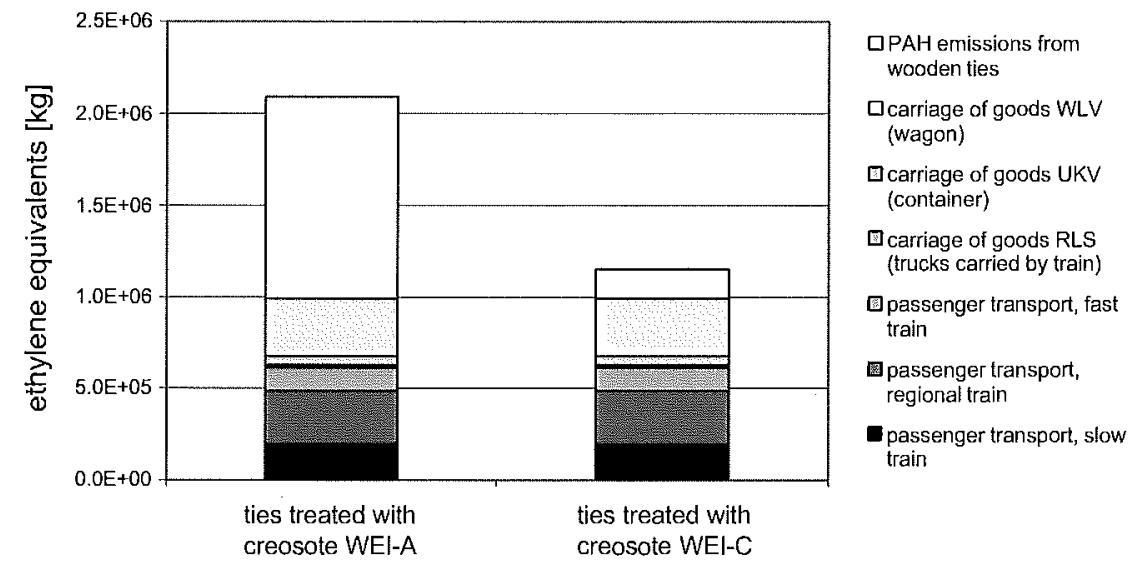

Fig. 8. Impact category "photochemical ozone creation" per year, based on rail traffic (Switzerland 1995)

Abb. 8. Bewertungskategorie "Photochemisches Ozonbildungspotential" pro Jahr, basierend auf dem Schienenverkehr (Schweiz 1995)
PAH fluxes for five PAH (acenaphthene, fluorene, phenanthrene, anthracene, and fluoranthene) from creosote treated wood between $2.57 \pm 1.52 \mathrm{mg} /\left(\mathrm{m}^{2} \times\right.$ day $)$ at $4^{\circ} \mathrm{C}$ and $29.5 \pm 6.1 \mathrm{mg} /\left(\mathrm{m}^{2} \times\right.$ day $)$ at $30^{\circ} \mathrm{C}$. OSPARCOM (1996) reports emission factors for $10 \mathrm{PAH}$ (naphthalene, anthracene, phenanthrene, fluoranthene, benz[a]anthracene, chrysene, benzo[k]fluoranthene, benzo[a]pyrene, benzo[a]perylene and indeno[1,2,3-cd]pyrene) of creosote treated wood. The mean total flux given is $5994 \times 10^{-6} \mathrm{~kg} /$ ( $\mathrm{m}^{2}$ xyear) into the soil (reported to be $2 / 3$ of the total amount). This figure corresponds to a total flux (soil and air) of $24.6 \mathrm{mg} /\left(\mathrm{m}^{2} \times\right.$ day $)$.

\section{4}

\section{Inventory and total emissions of creosote, PAH and phenols}

About 9 million wooden railroad ties are installed in the Swiss railway network. Based on applied quantities of creosote of $6 \mathrm{~kg}$ (oak, $20 \%$ of the ties) and $15 \mathrm{~kg}$ (beech, $80 \%$ of the ties), respectively, the cumulated inventory of creosote in the Swiss railway network is estimated to $116000 \mathrm{t}$. The cumulated inventory of the $16 \mathrm{EPA}-\mathrm{PAH}$ adds up to $23400 \mathrm{t}$, including $1100 \mathrm{t}$ naphthalene and $18 \mathrm{t}$ benzo[a]pyrene. The cumulated inventory of phenolic compounds is estimated to $232 \mathrm{t}$. According to our study, about $1710 \mathrm{t}$ of creosote components are being emitted by the ties of the Swiss railway network, every year. Based on the values reported above, yearly emissions of 2- and 3ring EPA-PAH add up to 139 t. Cumulated emissions of phenolic compounds are in the order of $4 \mathrm{t}$ per year.

\section{5}

\section{Life Cycle Analysis}

The PAH emissions from creosoted wooden ties have an enormous influence on the two effect oriented impact categories photochemical ozone creation and human toxicity. For all other impact categories, the PAH emissions are not relevant (see Fig. 6). Less than $4 \%$ of the total human toxicity potential are caused by $\mathrm{PAH}$ emissions from wooden ties. The rail traffic itself, including its upstream processes (such as energy production) is much more important (see Fig. 7). It is also quite different from the potential of photochemical ozone creation. More than $50 \%$ of the total impact are caused by PAH emissions, when creosote according to WEI-A is used. The use of the

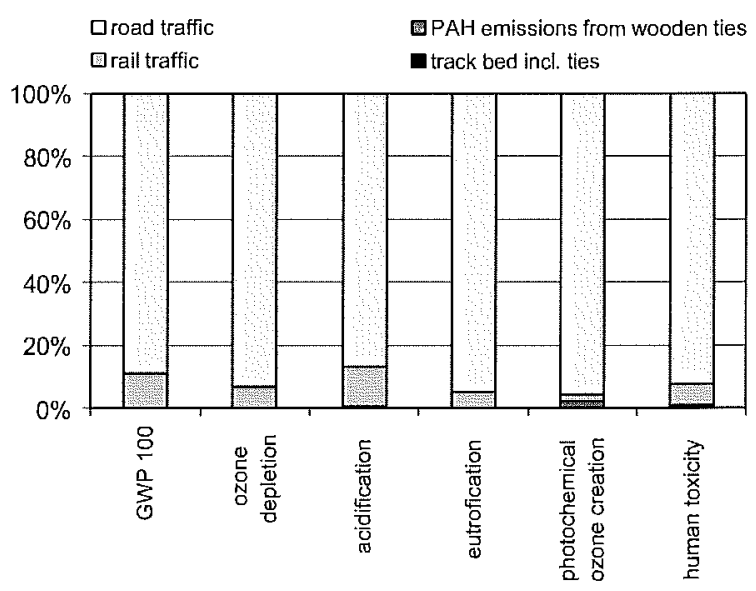

Fig. 9. Environmental impacts per year, based on road and rail traffic (Switzerland 1995)

Abb 9. Umwelteinwirkungen pro Jahr, bezogen auf Schienen- und Straßenverkehr (Schweiz 1995)

new creosote according to WEI-C leads to an improved rating in the impact category photochemical ozone creation. Less than $14 \%$ of the total impact were caused by PAH emissions if creosote according to WEI-C is used, as Swiss Federal Railway are doing today (Fig. 8). If the road traffic (including its upstream processes) is included in this comparison (Fig. 9), it is clearly dominating all impact categories.

\section{4}

\section{Conclusions}

This study demonstrates, based on a life cycle analysis, that emissions of PAH from creosoted railroad ties contribute to the impact categories "photochemical ozone creation" and "human toxicity". Compared to other sources of PAH emissions of rail- and road traffic, however, the impact of PAH emissions from creosoted ties is rather low. The highest potential for the reduction of these two impact categories exists at the reduction of road traffic, especially on motorized individual traffic.

Attempts are being made to optimize the composition of creosote in order to minimize PAH emissions from creosoted wooden railroad ties. By these means, creosoted railroad ties showing many technical advantages should be able to maintain their future market share. 


\section{References}

Baileys RT, Webb DA (1987) Proceedings of the American WoodPreservers' Association, 163

Bergqvist G, Holmroos S (1994) 25th Annual Meeting of the International Research Group on Wood Preservation, IRG Stockholm Cooper PA (1994) Investigation of the Residual Creosote Content and Leaching of Creosote Components from Creosote Treated Ties Removed from Service, University of Toronto, Environment Canada EMIS software (2000) version 3.0, Carbotech AG, Basel

Frischknecht (1996) Ökoinventare von Energiesystemen. 3. Auflage. Im Auftrag des Bundesamtes für Energiewirtschaft. ETH Zürich, PSI Villigen, Switzerland

Gevao, B, Jones KC (1998) Environ. Sci. Technol. 32:640-646

Havermans JBGA (1993) The Shower Test Method. Proceedings of the Second International Symposium on Wood Preservation, Int. Research Group on Wood Preservation, Doc. IRG/WP/93-50001:77-90 Heijungs R, Guinée JB (1992) Environmental Life Cycle Assessment of Products, Guide and Background, Centre of Environmental Science, Leiden University, The Netherlands

Hudson NJ, Murphy RJ (1997) 28th Annual Meeting of the International Research Group on Wood Preservation, IRG Stockholm Kohler M (2000) EMPA Research Report 200'055, Swiss Federal Laboratories for Materials Testing and Research, ISSN 0258-9745, Dübendorf
Kohler M, Künniger T, Schmid P, Gujer E, Crockett R, Wolfensberger M (2000) Environ Sci Technol 34:4766-4772

Künniger T, Richter K (1998) EMPA Research Report 115/38, Swiss Federal Laboratories for Materials Testing and Research, Dübendorf Maibach (1995) Ökoinventar Transporte, SPP Umwelt, Verlag INFRAS, Infras AG Zürich OSPARCOM-Oslo and Paris Conventions for the Prevention of Marine Pollution (1996) Working Group on Diffuse Sources (DIFF) PAH Emission Factors with Procedural Guidance for the Submission of PAH Emission Data, Norway, DIFF 97/7/3-E(L), Cadiz, 30.9-3.10.96 Petrowitz H-J, Becker G (1976) Holz Roh-Werkstoff 34:315

Petrowitz H-J, Krüger H (1991) Holz Roh- Werkstoff 34:349-352 Rotard W, Mailahn W (1987) Anal Chem 59:65

Schwanninger K (1998) personal communication, Swiss Federal Railways, Basel

Streckert G (1989) Die Holzschwelle 100:28

The Commission of The European Communities (1999) Document number C(1999) 3425, 1999/833/EC, Official Journal of the European Communities, 22.12.1999, L 329/43

Webb DA (1998) personal communication, Creosote Council II, P.O. Box 160, Valencia, Pennsylvania 16059, USA

Western-European Institute for Wood Preservation, Allée Hof-terVleest 5, boîte 4, B-1070 Bruxelles 